\title{
Full realization principle for the identification of ideational grammatical metaphor: nominalization as example
}

\author{
Bingjun Yang \\ Department of English, Shanghai Jiao Tong University, Shanghai, China
}

\begin{abstract}
When a clause like glass cracks more quickly is rankshifted and nominalized as glass crack growth rate, ideational grammatical metaphor (IGM) occurs. However, embedded clauses (e.g. the fact that it had been shown to be a forgery ruined his argument) are also rankshifted and nominalized, but they cannot be regarded as IGMs. This issue of embedding has tended to be relatively under studies within the theory of systemic functional linguistics (SFL). In order to tackle this issue, we propose a principle (i.e. the full realization principle, FRP) which operates in parallel with the principle of rankshift for the identification of IGMs. Under the FRP principle, a nominalization may be full, intermediate or raw in realization, but only the full nominalization which is compressed both in meaning and form can be regarded as IGM. As a necessary supplement to the rankshift principle, FRP helps distinguish nominalizations which are IGMs from those which are not, and the issue of embedding will not be a problem any longer. This in turn offers a new perspective to the categorization of nominalization in general.
\end{abstract}

\section{ARTICLE HISTORY}

Received 21 May 2019

Accepted 16 December 2019

\section{KEYWORDS}

Ideational grammatical metaphor; rankshift principle; full realization principle; nominalization

\section{Introduction}

Recent versions of An Introduction to Functional Grammar (IFG) (Halliday and Matthiessen 2004, 2014) inform readers well of the rankshift principle for determining ideational grammatical metaphor (IGM) by saying that:

The general tendency for ideational metaphor is to 'downgrade' the domain of grammatical realization of a semantic sequence, figure or element - from clause nexus to clause, from clause to group/phrase, and even from group or phase to word (Halliday and Matthiessen 2004: 646, 2014, 719).

The word "downgrade" is emphasized here to suggest that the rankshift principle should be followed for the realization of IGM. This is consistent with Halliday's "general drift of grammatical metaphor" (Halliday 1998/2004a, 42). The problem is that embedded clauses in English are all downgraded (rankshifted) in status. Does it mean that embedded clauses are all IGMs after the rankshift principle?

In the earliest categories of IGM drawn by Ravelli (1988), embedded clauses are considered as IGMs. For example, the finite clause All it can do and the non-finite clause to retaliate in All it can do is to retaliate are considered as IGMs. Similarly, Matthiessen 
$(1995,502)$ in discussing interpersonal metaphor thinks that clause (proposition or proposal) can also be modalized or modulated by being embedded. For example, That Henry has gone to London seems very likely and For Henry to go to London is necessary are considered as interpersonal metaphors.

Since speech function is the determining factor for interpersonal metaphor, Matthiessen's view on embedded clauses here is reasonable in its own right. By contrast, to include embedded clauses into IGM results in conflict because English (many other languages as well) is full of embedded clauses. This conflict troubled Huddleston (1988) soon after the first edition of IFG was published. It remains disturbing to a number of systemicists today: why are some rankshifted and nominalized expressions not considered as IGMs? For example, who came to dinner in the man who came to dinner, and That all this wealth might some day be hers in That all this wealth might some day be hers has simply never occurred to her(Halliday and Matthiessen 2014: 198, 491) are rankshifted as embedded clauses, but they are not regarded as IGMs. Moreover, why is Type [11] in the typology of IGM (i.e. the fact/phenomenon of) by Halliday and Matthiessen (1999, 246-248) a typical embedding? Does it mean that some embeddings may be classified as IGMs?

The purpose of the present study, therefore, is to tackle the issue of embedding in the identification of IGM. We will outline the theory of IGM and then provide a review of the issue of embedding in detail. Then, the full realization principle (FRP) will be proposed for the identification of IGM by which the problem of embedding can be overcome. We assume that the rankshift principle and FRP may work together for good consistency in the identification of IGM.

\section{A glimpse of ideational grammatical metaphor}

The theory of metaphor in its traditional sense has been popular since the publication of Aristotle's Rhetoric, and the theory of conceptual metaphor has been widely known in the academic world since the publication of Metaphors We Live By (Lakoff and Johnson 1980). Grammatical metaphor was seeded in Halliday's article "Grammar, society and the noun" (Halliday 1966/2003) and it formally appeared in an article which compares English with Chinese in 1980s (Halliday 1984). The comprehensive version was first provided in the first edition of IFG (Halliday 1985). With further illustrations and improvements by Halliday, Matthiessen and other systemicists, grammatical metaphor has become an illuminating perspective on the metaphorical mechanism of linguistic components, attracting increasing attention from pragmaticists, socio-linguists, translation theorists, and applied linguists.

According to Halliday and Matthiessen $(1999,48)$, "The phenomena of experience are of three orders of complexity: elementary (a single element), configurational (configuration of elements, i.e. a figure) and complex (a complex of figures, i.e. a sequence)". When an element in semantics is realized by a group in lexicogrammar, a figure by a clause, and a sequence by a clause nexus, we have the direct correspondence between meaning and form, and no grammatical metaphor is involved. See the following quotation for a better understanding:

The grammar of every natural language is a theory of human experience ... The grammar breaks down the continuum of experience into figures, each figure representing 
a "happening" of some kind; and it does this by means of the clause: you will hear small children saying things like (from my own records) tiny bird flew away, that tree got no leaf on, put butter on toast, and so on. It also analyses each figure into different types of elements: the happening itself, like flew, got, put and so on; and the various participating entities and circumstantial elements that surround it: tiny bird, that tree, butter, away, on toast ... And thirdly it joins the figures into sequences by means of various logical semantic relations such as time and cause; e.g. but in That tree got leaf on but that tree got no leaf on (Halliday 1995/ $2004,9)$ (emphasis in original)

This natural directness in realization can be taken as an important manifestation of congruence in ideational meaning (Steiner 2002b). However, if a sequence is realized by a clause or a figure realized by a group, the grammatical form becomes indirect and a tension rises between semantics and lexicogrammar. This indirect (incongruent) form in lexicogrammar is called IGM (Halliday and Matthiessen 1999, 227). See (1) from Halliday (1998/2004a, 34):

(1). a. Glass cracks more quickly the harder you press on it.

b. The rate of glass crack growth depends on the magnitude of the applied stress.

c. Glass crack growth rate is associated with applied stress magnitude.

As was noted by Halliday, the original version of the instances in (1) above is (1b) which was taken from the article entitled "The fracturing of glass" in Scientific American by Michalske and Bunker. The instances are different ways for expressing the same meaning. The sequence in (1a) is realized by two clauses (i.e. glass cracks quickly, you press on it), and the relationship between semantics and lexicogrammar is direct. The one-to-one mapping of a doing figure (glass cracks quickly, you press on it) onto a material process (crack, press) in (1a) shows a direct realization (i.e. the congruent form).

The clause nexus in (1a) used to realize a sequence is then rankshifted ${ }^{1}$ (transcategorized) downward into groups (the rate of glass crack, the magnitude of the applied stress) respectively in (1b). In other words, the sequence has been compressed and expressed by a figure. Thus, (1b) becomes the incongruent form and IGM occurs. The clause in (1b) is rankshifted downward further and we have nominalized groups in (1c) (i.e. growth rate, stress magnitude). The clause in (1c) is thus further metaphorized as a typical IGM. In nominalization, "some element other than a noun ... has nominal status assigned" (Halliday 1966/2003, 58). Both (1b) and (1c) concern metaphoricity in two senses: nominalization and clause nexus transcategorized into clause.

The theory of grammatical metaphor is "an important step forward in systemic functional linguistics" (Ravelli 2003, 38). The congruent forms evolve "earlier in the language"; they are "learnt earlier by children" and they "come earlier in the text" (Halliday and Matthiessen 1999, 235). Among many other enlightenments, it is grammatical metaphor that underpins linguistic creativity (ontogenesis), human language development (phylogenesis), and concept formation (logogenesis).

Current literature on IGM includes the following topics: theoretical pondering (e.g. Christie and Martin 2007; Davidse 1991/1999; Lassen 2003a, 2003b; Simon-Vandenbergen, Taverniers, and Ravelli 2003; Steiner 2002b; He and Yang 2014, ; Yang 2018, 2019); clarification and explanation (e.g. Devrim 2015; Liardét 2016b; Taverniers 2002); ontological observations (e.g. Derewianka 1995; Painter 2003); cross-linguistic studies (e.g. 
Byrnes 2009; Magnusson 2013; Yang 2014); applications and the use of GM in ESL/FL learner writing or language development (e.g. Bateman 1990; Liardét 2013, 2016a; O'Halloran 1996; Ryshina-Pankova 2010, 2015; Schleppegrell 2008; Steiner 2002a; He and Yang 2018). As an economical means of packing information up (Halliday 1998/ 2004a), grammatical metaphor has been found as a common feature of scientific writing (e.g. Banks 2005; Biber and Gray 2016; Colombi 2006; Martin 1993).

These studies have greatly enhanced the understanding as well as the application of grammatical metaphor, but the status of embedded clauses has not been made clear with regard to IGM. Those who try to get a grip of grammatical metaphor, non-systemicists in particular, may get confused provided that the issue of embedding is not well-explained in the case of IGM.

\section{The status of embedded clauses in ideational grammatical metaphor}

In his review article of the first edition of IFG (Halliday 1985), Huddleston (1988) raised some problems among which to view a clause as Head of a nominal group is considered problematic (e.g. the man who came to dinner stole the silver; why she did it remains a mystery). On commenting Halliday's example the fifth day saw them at the summit, Huddleston said that treating such examples as metaphorical "is very plausible" (Huddleston 1988, 168), for the semantic restriction is similar to such clauses as the fact that it had been shown to be a forgery ruined his argument. The core reason in Huddleston's criticism of "grammatical metaphor" lies in the vague status of embedded clauses.

When comparing the evening the guests ate ice cream and then swam gently (the congruent) with the guests' supper of ice cream was followed by a gentle swim (the metaphorical), Halliday $(1994,344)$ states that the Participants "the guests" and "ice cream" here have been embedded as Modifiers. In the third and fourth editions of IFG, embedded clauses are discussed in the section of interpersonal metaphor: embedded "fact" clauses (e.g. the strongest belief of all is that there is no trace.). Except for these, embedding is not mentioned in the discussion of IGM (See Halliday 1999/2004).

IGM types in Halliday (1998/2004a, 24-48) and Halliday and Matthiessen (1999, 246-248) are sufficient in themselves. One problem with the typology is still about the unclear status of embedding, Type [11] in particular. Type [11] in the typology is involved with embedding. One interpretation may be that a "covert" clause has been rankshifted and embedded as a modifier of fact/phenomenon. In other words, a clause has been rankshifted and embedded as a nominalization to modify fact/phenomenon and IGM occurs. Since numerous such antecedents can be found in English, this remains to be clarified.

How about the status of typical embedded clauses in the theory of grammatical metaphor, then? When the embedded clause (or phrase) functions as Head, notational simplification (e.g. as Subject) "does not affect the status of the embedded element as a nominalization" (Halliday and Matthiessen 2014, 491). Both subjects and objects function as Participants in a clause, and it is reasonable to say that embedded clauses which function as subjects (or objects or complements) may all be nominalizations. Appositives may also be regarded as nominalizations. See the following examples from Quirk et al. 
(1985):

(2) Nominal that-clauses function as subject, object or appositive:

a. That the invading troops have been withdrawn has not affected our government's trade sanctions.

b. I noticed that he spoke English with an Australian accent.

c. Your criticism, that no account has been taken of psychological factors, is fully justified. (Quirk et al. 1985, 1049)

(3) Wh-clauses function as subject, object, complement or appositive:

a. What I want is a cup of hot cocoa.

b. You should see whoever deals with complaints.

c. April is when the lilacs bloom.

d. I'll pay you the whole debt: what I originally borrowed and what I owe you in interest. (Quirk et al. 1985, 1058)

(4) Nominal non-finite clauses function as subject or appositive:

a. Watching television keeps them out of mischief.

b. His current research, investigating attitudes to racial stereotypes, takes up most of his time. (Quirk et al. 1985: 1061-1063)

The italicized clauses in the examples above are all rankshifted and embedded, functioning as Participants, which are all nominalized according to Halliday and Matthiessen (2014). However, it is not convincing to consider these nominalizations as IGMs because there will be numerous embedded clauses in a very short passage, spoken language in particular (cf. Halliday 1989).

As a leading scholar in SFL, Fawcett (2008) considers the concept of "grammatical metaphor" problematic for the reason that it "requires enormous extensions to the descriptive apparatus of the Sydney Grammar" (Fawcett 2008, 164). The so-called "enormous extensions" are mainly about embedding in our understanding. See the three types of nominalization drawn by Fawcett (forthcoming).

(5) a. We watched Ivy's careful descent of the Hörnli Ridge (Type 1 nominalization)

b. We watched Ivy's careful descending of the Hörnli Ridge (Type 2 nominalization)

c. We watched Ivy's carefully descending the Hörnli Ridge (Type 3 nominalization)

Besides using a nominal group to refer to an event, according to Fawcett (forthcoming), we can use a clause to refer to an object. Fawcett terms this as "clausalization". See (6) from Fawcett (forthcoming).

(6) a. What you saw wasn't what I saw.

b. It was because he overslept that he was late.

c. Why he was late was because he overslept

The term "clausalization" suggests that such clauses in (5) and (6) should be nominalizations but they cannot be taken as IGMs in Fawcett's view. Thus, the issue of embedding seems to be the Achilles' heel to the theory of grammatical metaphor. This problem, fortunately, can be solved if we follow the FRP principle to distinguish full nominalizations (IGMs) from other nominalizations (embedded clauses and dead metaphors). 
Figure 1. Basic functional roles in a typical clause.

\section{The solution: the full realization principle}

A feasible approach to address the issue of embedding is to start with the functional roles and its variations in a clause. No matter how many embedded clauses are involved in, a typical clause is composed of Participant, Process, and Circumstance in terms of SFL (Figure 1).

Embedded clauses as modifiers may be used to elaborate the functional roles (Participant, Process, or Circumstance) in various ways. The modifiers, whether finite or non-finite, are embedded to either Participant or Circumstance. The status of a clause does not change even when many other clauses are embedded to the roles because the embedded clauses when used as modifiers tend to elaborate the functional roles. Whatever role an embedded clause is to elaborate, the embedded clause itself may be presented in three basic realizations: full, intermediate or raw.

Let us illustrate this briefly. A clause describes an event or an action (e.g. a man rides $a$ horse). This clause may be embedded to a Head and compressed into a nominalization (the man who rides a horse). This event or action may become very frequent in a context, and people may pack it up (the man's riding a horse). Some Participants (e.g. man) are not necessary to be specified in certain contexts and we have a more contracted form (riding a horse). With many people doing the same thing (riding horses), the activity may be referred to as a phenomenon (horse riding). With time going on, people use a single term (ride) to mean the activity. Soon afterwards, this term may be extended to cover other facilities (e.g. bike ride, car ride etc.). See (7):

(7) a. a man who rides a horse is called a horseman (COCA, FIC)

b. a man who rides a horse

c. riding a horse

d. a man's riding a horse

e. horse riding

f. ride

Examples in (7) are based on (7a) which is directly quoted from a fictional passage in COCA. They are all involved with nominalization. The difference is that the embedded clauses (i.e. who rides a horse) in (7a) and (7b) are still in the form of a clause. In other words, they are only nominalized/compressed in meaning, not in form. By contrast, (7d) and (7e) are nominalized/compressed both in meaning and form. (7c) is partly compressed in meaning and form. (7f) as a noun is demetaphorized because it has become a frequently-used typical noun in English. Accordingly, three basic types of nominalization may be identified as follows:

Full nominalization: horse riding (nominalized both in meaning and form)

Intermediate nominalization: riding a horse (nominalized partly in meaning and partly in form)

Raw nominalization: a man who rides a horse (nominalized only in meaning) 
The three types are all nominalizations, but it does not mean that they are all IGMs. Among the three types, only full nominalization which is compressed both in meaning and form can be regarded as IGM. Intermediate nominalization is partly metaphorical and raw nominalization is not metaphorical at all. This applies to verbalization and other categories of IGM. Thus, one important principle for identifying IGM is the full realization principle (FRP), according to which only full realizations are compressed both in meaning and form. With this principle, embedded clauses will no longer be a problem because they are usually raw realizations which cannot be IGMs. Raw realizations are not necessarily the "congruent" either because "congruence" refers to the most natural and direct expressions (See Steiner 2002b) rather than nominalizations or verbalizations. For example, the congruent realization for (7d) and (7e) is a man rides a horse which is a typical clause, not a man who rides $a$ horse which is a nominalization.

To generalize this further, we may have three basic realizations as well in dealing with other manifestations of IGM:

Full realization (realized/compressed both in meaning and form)

Intermediate realization (realized/compressed partly in meaning, partly in form)

Raw realization (realized/compressed only in meaning)

"Realized/compressed both in meaning and form" here means that a clause nexus (or a clause or a group) has been rankshifted into a clause (or a group or a word) with the basic meaning being retained. "Realized/compressed only in meaning" means that the form is still in its original form (i.e. No transcategorization takes place) but it is embedded to a specific component.

With embedding being treated properly in this manner, the rankshift principle by Halliday and Matthiessen $(2004,2014)$ will be in good operation for the identification of IGM. Thus, IGM is a "product" of downward rankshift because IGM won't occur without rankshifting. More importantly, embedded clauses as demonstrated above are not IGMs because they are realized/compressed in meaning but not in form. Only the fully-realized /compressed can be IGMs.

The FRP principle can be applied to nominalization, verbalization and other manifestations of IGM. In the following section, we will take nominalization as example to illustrate the principle in detail, with a short discussion on its relevance to "nominalization" by linguists other than systemicists.

\section{Nominalization as an example}

Four types of nominalization contribute to IGM, and they are all involved with rankshift: either from clause complex to clause or from clause to group. See the specific categories below with instances. Note that the instances are based on those in the typology of grammatical metaphor by Halliday (1998/2004a, 24-48) and Halliday and Matthiessen (1999, 246-248) and we have checked the patterns for their validity in BNC or COCA:

Nom1: relator $\Rightarrow$ sentity (clause complex $\square$ clause)

e.g. I stayed behind so I could see you = the cause of my staying behind is to see you if you try hard it might work = the condition for it to work is to try hard

Nom2: process+entity (clause+group) 
e.g. a tadpole transforms into a frog $=$ the transformation of a tadpole

she'll try to call him again = her attempt of calling him again

they're going to be massive = their prospect to be massive

they can run fast $=$ the possibility of fast running

they could be right $=$ the potential to be right

Nom3: quality $\Rightarrow$ entity (clause+group)

e.g. the price is unstable $=$ instability of price

Nom4: circumstance $\Rightarrow$ entity (clause $\Rightarrow$ group)

e.g. Jane stays with her = Jane's accompaniment

we went to Prague last year = Prague as our destination last year

dust is on the surface $=$ surface dust

According to FRP, a nominalized expression may be metaphorical, but not all nominalized expressions are IGMs; among the three general types of nominalization (full, intermediate, and raw), only the full nominalization which is compressed both in meaning and form can be IGM. Since a typical clause contains the functional roles of Participant, Process and Circumstance, degrees of nominalization can be adjusted if any of these roles are nominalized/compressed. See (8) from Fawcett (forthcoming) for example.

(8) a. We watched Ivy's careful descent of the Hörnli Ridge (full nominalization)

b. We watched Ivy carefully descending the Hörnli Ridge (intermediate nominalization)

c. We watched Ivy's carefully descending the Hörnli Ridge (raw nominalization)t

The embedded clause in (8c) is rankshifted and nominalized, but it is not packed up in the form of a group or a word. It is still in the form of a clause. In other words, it is not fully nominalized/compressed and shall be classified as raw nominalization. The position of the embedded clause can be different. See (9) for example.

(9) That Ivy is carefully descending the Hörnli Ridge is watched (raw nominalization)

Not only Process (e.g. someone descends) can be nominalized (e.g. descent or descending), other functional roles can also be nominalized. Thus, we may have the following realizations:

(10) a. Ivy is careful when she descends the Hörnli Ridge.

b. Ivy descends the Hörnli Ridge with care. (Quality nominalized)

(11) a. Ivy acts in a careful way when she descends the Hörnli Ridge.

b. Ivy's care in descending the Hörnli Ridge ... (Circumstance nominalized).

(12) a. Ivy is careful when she descends the Hörnli Ridge.

b. Ivy is careful at the time of descending the Hörnli Ridge (Relator nominalized).

Theoretically speaking, every functional role in a clause (i.e. Participant, Process, Circumstance, Relator and Quality) can be nominalized/compressed, but IGM cannot occur until a full nominalization is produced out of downward rankshift. The general tendency is that a high-ranked component usually shifts to be a low-ranked component, bringing forth metaphoric syndrome (i.e., the cline of metaphorical degrees) ${ }^{2}$ which is prevalent for IGM. Using Fawcett's example as the anchoring instance (i.e. we watched ivy carefully descending the Hörnli Ridge), we may draw the syndrome for nominalization in Figure 2. 


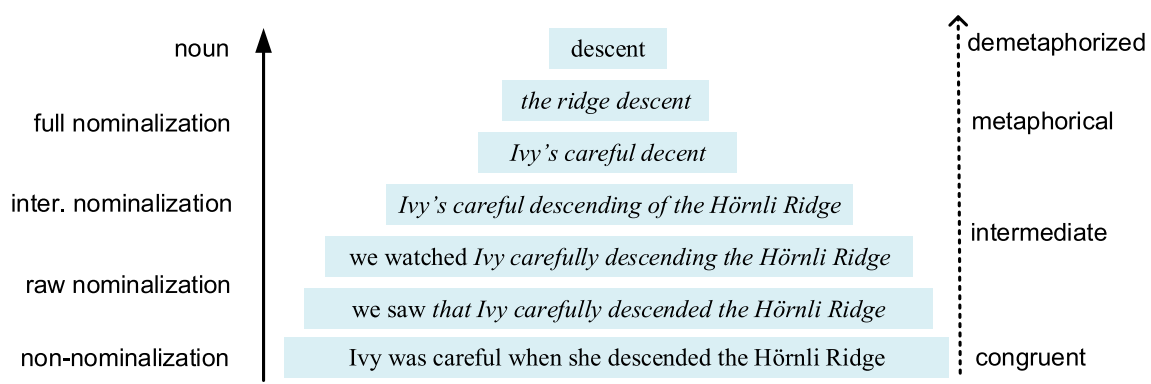

Key: inter.-intermediate; the italicized refer to those that have been nominalized.

Figure 2. The metaphorical syndrome: nominalization.

The finite clause in Figure 2 (i.e. Ivy carefully descended the Hörnli Ridge) may become a nominalization when embedded, but it is what we call "raw nominalization" which is nominalized/compressed only in meaning. These raw nominalizations are neither congruent nor metaphorical, but they are closer to the congruent expression. The non-finite clause (i.e. Ivy carefully descending the Hörnli Ridge) is nominalized/compressed partly in meaning and partly in form, being partially metaphorical. Full nominalizations (i.e. the ridge descent and Ivy's careful descent) are typical IGMs. They may develop further and become nouns so as to refer to specific entities, and at this stage they become demetaphorized as dead metaphors (e.g. descent).

As to Type [11] (the fact/phenomenon of), it may be considered as full nominalization if a clause is rankshifted. For example: the phenomenon of after-burning (OED) may be considered as a group rankshifted from a clause. It is not "the phenomenon of" but the fully-realized nominalization "after-burning" that is metaphorized. In English, we may have numerous such antecedents (e.g. the news/act/point/example of ...) and their status of being IGMs depends on whether clauses are rankshifted and embedded as full nominalizations. If the embedded clauses are rankshifted as raw nominalizations, the phenomenon that a coagulated sol can be liquefied (OED) for example, there will be no IGMs because raw nominalizations are realized/compressed only in meaning. A raw nominalization is one that is close to the congruent but far from the metaphorical (See Figure 2).

Nominalizations are "not only pervasive but theoretically significant" (Langacker 1991, 22 ), and it is true that "[n]ominalizations reclassify a processual starting point, of which the 'size' can vary from a verb stem to a processual expression with complements or even a full clause"(Heyvaert 2010, 73). With different categorizations of nominalization, distinctive insights may be brought to the audience. To observe from the categories of nominalization we have drawn according to FRP and the rankshift principle in terms of IGM, "event and result nominalizations" (Lees 1960) may be considered as full realizations and they are most probably IGMs; some "action nominals" (including infinitives and participles) (Nikolaeva 2010) or some "-ing nominalizations" (Chomsky 1970) are usually intermediate nominalizations which are partially metaphorical; and "embedded clauses as nominalizations" (Lehmann 1988) are usually raw nominalizations which are close to the congruent.

Other categorizations of nominalization can also be explained in terms of IGM. One categorization of nominalization starts from the status: "participant nominalization" 
(Koptjevskaja-Tamm 1993) refers to derived nominal constituents that function as arguments with referential status within a clause; "event nominalization" or "action nominalization" refers to the nominalization of an action. Another categorization focuses on the grammatical function: lexical nominalizations have the same morphosyntactic characteristics as nonderived nouns (Comrie and Thompson 1985); clausal nominalizations resemble predicative clauses in retaining verbal features such as tense, aspect, and mood marking (Post 2011). Clausal nominalization is further classified as embedded vs. nonembedded nominalization. If we observe these types of nominalization from the perspective of IGM (Figure 2), we may have three basic categories: full, intermediate and raw. Participant nominalizations are usually fully compressed/nominalized while event/action nominalizations may or may not be fully compressed as IGMs. Full nominalizations tend to be lexical, and raw nominalizations are always clausal, either embedded or nonembedded. Among the realizations, full nominalizations are IGMs.

Metaphor of the derivational ecosystem "helps us to see two different facets of nominalization in English" (Lieber 2016, 9). Grammatical metaphor which focuses on the inter-relations of linguistic components, also helps us to observe nominalization from a brand-new perspective. Verbalization, adjectivization, and adverbialization can also be conveniently observed from the IGM perspective, which requires the space of another article for discussion.

\section{Conclusion}

Metaphorization on the grammatical level brings life to creativity in linguistic expressions rather than in individual words or concepts (Concepts represented by nouns may be developed later out of dead metaphors). With various options in expressing the same meaning by means of IGM, we can represent things, events and ideas strategically to fulfil purposes in various contexts.

FRP helps overcome the conflicts in the treatment of embedding in IGM. According to FRP, only fully-realized/compressed expressions can be taken as IGMs. To identify IGM, FRP and the rankshift principle should be simultaneously used for a better result. With the two principles operating together, nominalizations can be conveniently distinguished as full, intermediate or raw categories. As "a rich resource for expanding the overall meaning potential" (Halliday 2013, 34), the theoretical aspect of IGM needs more exploration.

Acknowledgements: I would like to thank the anonymous reviewers for their insightful comments. Thanks also go to Prof. Yanmei Gao at Peking University for inviting me to give a talk on this topic during which she and the graduate students provided helpful suggestions.

\section{Notes}

1. Rank in SFL refers to "the hierarchy of units according to their constituency potential" (Halliday and Matthiessen 1999, 4) and the units include clause nexus (usually clause complex), clause, group/phrase, word, and morpheme. When a unit (e.g. clause) is replaced by another unit next below (e.g. group) for the purpose of meaning variation, rankshift occurs.

2. Syndrome as a term is used by Halliday to differentiate the shift in lexical metaphor from that in grammatical metaphor. In lexical metaphor, a simple opposition is set up between two 
terms where no degrees may be drawn between. By contrast, the shift between categories in grammatical metaphor is usually more than one degree of metaphoric displacement. A congruent instance may proceed step by step towards the metaphorical, and the intermediate realizations may be more or less metaphorical. This phenomenon is called metaphoric syndrome (Halliday 1998/2004b, 79).

\section{Disclosure statement}

No potential conflict of interest was reported by the author(s).

\section{Funding}

This research is Sponsored by Shanghai Pujiang Program (18PJC082).

\section{Notes on contributor}

Dr. Bingjun Yang was once a visiting professor at the University of Illinois at Urbana-Champaign and Basel University. He is now a tenured full professor of systemic functional linguistics at Shanghai Jiao Tong University. His research articles appeared in journals like Language Sciences (2004), Australian Journal of Linguistics (2014, 2015, 2018), Journal of Quantitative Linguistics (2015), Journal of World Languages (2017), Lingua (2018), and Social Semiotics (2019). His recent academic books include the co-authored Language Policy: A Systemic Functional Linguistic Approach (Routledge, 2017) and Absolute Clauses in English from the Systemic Functional Perspective: A Corpus-based Study (Springer, 2015).

\section{References}

Banks, D. 2005. "On the Historical Origins of Nominalized Process in Scientific Text." English for Specific Purposes 24 (3): 347-357. doi:10.1016/j.esp.2004.08.002.

Bateman, J. A. 1990. "Finding Translation Equivalents: An Application of Grammatical Metaphor". In Proceedings of the 13th conference on Computational linguistics (pp. 13-18). http://doi.10.3115/ 997939.997942

Biber, D., and B. Gray. 2016. Grammatical Complexity in Academic English: Linguistic Change in Writing. Cambridge: Cambridge University Press.

Byrnes, H. 2009. “Emergent L2 German Writing Ability in A Curricular Context: A Longitudinal Study of Grammatical Metaphor." Linguistics and Education 20 (1): 50-66. doi:10.1016/j. linged.2009.01.005.

Chomsky, N. 1970. "Remarks on Nominalization." In Readings in English Transformational Grammar, edited by R. A. Jacobs and P. S. Rosenbaum, 184-221. Waltham, MA: Ginn \& Company.

Christie, F., and J. R. Martin. 2007. Language, Knowledge and Pedagogy: Functional Linguistic and Sociological Perspectives. London \& New York: Continuum.

Colombi, M. C. 2006. "Grammatical Metaphor: Academic Language Development in Latino Students of Spanish." In Advanced Language Learning: The Contribution of Halliday and Vygotsky, edited by H. Byrnes, 147-163. London \& New York: Continuum.

Comrie, B., and S. A. Thompson. 1985. "Lexical Nominalization." In Language Typology and Syntactic Description, Grammatical Categories and the Lexicon, edited by T. Shopen, 349-398. Cambridge: Cambridge University Press.

Davidse, K. 1991/1999. Categories of Experiential Grammar. Clifton, Nottingham: Department of English and Media Studies, Nottingham Trent University.

Derewianka, B. 1995. Language Development in the Transition from Childhood to Adolescence: The Role of Grammatical Metaphor. Macquarie University. 
Devrim, D. Y. 2015. “Grammatical Metaphor: What Do We Mean? What Exactly Are We Researching?" Functional Linguistics 2 (1): 1-15. doi:10.1186/s40554-015-0016-7.

Fawcett, R. 2008. Invitation to Systemic Functional Linguistics through the Cardiff Grammar. London: Equinox.

Fawcett, R. forthcoming. Functional Syntax Handbook: Analyzing English at the Level of Form. London: Equinox.

Halliday, M. A. K. 1966/2003. "Grammar, Society and the Noun." In On Language and Linguistics, edited by J. Webster, 50-73. London: Continuum.

Halliday, M. A. K. 1984. "Grammatical Metaphor in English and Chinese." In New Papers on Chinese Language Use, edited by B. Hong, 9-18. Canberra: Contemporary China Centre, Australian National University.

Halliday, M. A. K. 1985. An Introduction to Functional Grammar. 1st edn. London \& New York: Edward Arnold.

Halliday, M. A. K. 1989. Spoken and Written Language. 2nd edn. Oxford: Oxford University Press.

Halliday, M. A. K. 1994. An Introduction to Functional Grammar. 2nd edn. London \& New York: Edward Arnold.

Halliday, M. A. K. 1995/2004. "Language and the Reshaping of Human Experience." In The Language of Science, edited by J. Webster, 7-23. New York \& London: Continuum.

Halliday, M. A. K. 1998/2004a. "Language and Knowledge: The 'Unpacking' of Text." In The Language of Science, edited by J. Webster, 24-48. New York \& London: Continuum.

Halliday, M. A. K. 1998/2004b. "Things and Relations: Regrammaticizing Experience as Technical Knowledge." In The Language of Science, edited by J. Webster, 49-101. New York \& London: Continuum.

Halliday, M. A. K. 1999/2004. “The Grammatical Construction of Scientific Knowledge: The Framing of the English Clause." In The Language of Science, edited by J. Webster, 102-134. New York \& London: Continuum.

Halliday, M. A. K. 2013. "Meaning as Choice." In Systemic Functional Linguistics: Exploring Choice, edited by L. Fontaine, T. Bartlett, and G. O'Grady, 15-36. Cambridge \& New York: Cambridge University Press.

Halliday, M. A. K., and C. M. I. M. Matthiessen. 1999. Construing Experience through Meaning: A Language-based Approach to Cognition. London: Continuum.

Halliday, M. A. K., and C. M. I. M. Matthiessen. 2004. An Introduction to Functional Grammar. 3rd edn. London: Hodder Arnold.

Halliday, M. A. K., and C. M. I. M. Matthiessen. 2014. Halliday's Introduction to Functional Grammar. 4th edn. London \& New York: Routledge.

He, Q. and Yang, B. 2014. "A Study of Transfer Directions in Grammatical Metaphor." Australian Journal of Linguistics 34 (3): 345-360. doi:10.1080/07268602.2014.898226.

He, Q. and Yang, B. 2018. "A Corpus-based Study of the Correlation Between Text Technicality and Ideational Metaphor in English." Lingua 203: 51-65. doi:10.1016/j.lingua.2017.10.005.

Heyvaert, L. 2010. "A Cognitive-functional Perspective on Deverbal Nominalization in English: Descriptive Findings and Theoretical Ramifications." In The Semantics of Nominalizations across Languages and Frameworks, edited by M. Rathert and A. Alexiadou, 51-82. Berlin \& New York: Walter de Gruyter.

Huddleston, R. 1988. "Review: Constituency, Multi-functionality and Grammaticalization in Halliday's Functional Grammar." Journal of Linguistics 24 (1): 137-174. doi:10.1017/S0022226700011592.

Koptjevskaja-Tamm, M. 1993. Nominalizations. London: Routledge.

Lakoff, G., and M. Johnson. 1980. Metaphors We Live By. Chicago \& London: University of Chicago Press.

Langacker, R. W. 1991. Foundations of Cognitive Grammar: Descriptive Application. Redwood, CA: Stanford University Press.

Lassen, I. 2003a. Accessibility and Acceptability in Technical Manuals: A Survey of Style and Grammatical Metaphor. Amsterdam \& Philadelphia: John Benjamins.

Lassen, I. 2003b. "Imperative Readings of Grammatical Metaphor: A Study of Congruency in the Imperative." In Grammatical Metaphor: Views from Systemic Functional Linguistics, edited by A.- 
M. Simon-Vandenbergen, M. Taverniers, and L. Ravelli, 279-308. Amsterdam \& Philadelphia: John Benjamins.

Lees, R. 1960. The Grammar of English Nominalizations. Bloomington, Indiana: Indiana University Press.

Lehmann, C. 1988. "Towards a Typology of Clause Linkage." In Clause Combining in Grammar and Discourse, edited by J. Haiman and S. A. Thompson, 181-225. Amsterdam \& Philadelphia: John Benjamins.

Liardét, C. L. 2013. "An Exploration of Chinese EFL Learner's Deployment of Grammatical Metaphor: Learning to Make Academically Valued Meanings." Journal of Second Language Writing 22 (2): 161-178. doi:http://doi.10.1016/j.jslw.2013.03.008.

Liardét, C. L. 2016a. "Grammatical Metaphor: Distinguishing Success." Journal of English for Academic Purposes 22: 109-118. doi:10.1016/j.jeap.2016.01.009.

Liardét, C. L. 2016b. "Nominalization and Grammatical Metaphor: Elaborating the Theory." English for Specific Purposes 44: 16-29. doi:10.1016/j.esp.2016.04.004.

Lieber, R. 2016. English Nouns: The Ecology of Nominalization. Cambridge: Cambridge University Press.

Magnusson, U. 2013. "Grammatical Metaphor in Swedish Monolingual and Multilingual Upper Secondary School Students' Writing." Functions of Language 20 (2): 250-281. doi:10.1075/ fol.20.2.05mag.

Martin, J. R. 1993. "Life as a Noun." In Writing Science: Literacy and Discursive Power, edited by J. R. Martin and M. A. K. Halliday, 242-293. London: Falmer Press.

Matthiessen, C. M. I. M. 1995. Lexicogrammatical Cartography: English Systems. Tokyo: International Language Science Publishers.

Nikolaeva, I. 2010. "Typology of Finiteness." Language and Linguistics Compass 4 (12): 1176-1189. doi:10.1111/j.1749-818X.2010.00253.x.

O'Halloran, K. L. 1996. The Discourses of Secondary School Mathematics. Murdoch University.

Painter, C. 2003. "The Use of a Metaphorical Mode of Meaning in Early Language Development." In Grammatical Metaphor: Views from Systemic Functional Linguistics, edited by A.-M. SimonVandenbergen, M. Taverniers, and L. Ravelli, 151-168. Amsterdam \& Philadelphia: John Benjamins.

Post, M. W. 2011. "Nominalization and Nominalization-based Constructions in Galo." In Nominalization in Asian Languages: Diachronic and Typological Perpsectives, edited by F. H. Yap, K. Grunow-Hårsta, and J. Wrona, 255-288. Amsterdam \& Philadelphia: John Benjamins.

Quirk, R., S. Greenbaum, G. Leech, and J. Svartvik. 1985. A Comprehensive Grammar of the English Language. New York: Longman.

Ravelli, L. 1988. "Grammatical Metaphor: An Initial Analysis." In Pragmatics, Discourse and Text: Some Systemically-inspired Approaches, edited by E. Steiner and R. Veltman, 133-147. London \& New York: Burns \& Oates.

Ravelli, L. 2003. "Renewal of Connection: Integrating Theory and Practice in an Understanding of Grammatical Metaphor." In Grammatical Metaphor: Views from Systemic Functional Linguistics, edited by A.-M. Simon-Vandenbergen, M. Taverniers, and L. Ravelli, 37-64. Amsterdam \& Philadelphia: John Benjamins.

Ryshina-Pankova, M. 2010. "Toward Mastering the Discourses of Reasoning: Use of Grammatical Metaphor at Advanced Levels of Foreign Language Acquisition." The Modern Language Journal 94 (2): 181-197. doi:10.1111/j.1540-4781.2010.01016.x.

Ryshina-Pankova, M. 2015. "A Meaning-based Approach to the Study of Complexity in L2 Writing: The Case of Grammatical Metaphor." Journal of Second Language Writing 29: 51-63. doi:10.1016/j. jslw.2015.06.005.

Schleppegrell, M. J. 2008. The Language of Schooling: A Functional Linguistics Perspective. London \& New York: Taylor \& Francis.

Simon-Vandenbergen, A.-M., M. Taverniers, and L. Ravelli, Eds. 2003. Grammatical Metaphor: Views from Systemic Functional Linguistics. Amsterdam \& Philadelphia: John Benjamins.

Steiner, E. 2002a. "Grammatical Metaphor in Translation: Some Methods for Corpus-based Investigations." Language and Computers 39 (1): 213-228. 
Steiner, E. 2002b. "Ideational Grammatical Metaphor: Exploring Some Implications for the Overall Model." Languages in Contrast 4 (1): 137-164.

Taverniers, M. 2002. Systemic-functional Linguistics and the Notion of Grammatical Metaphor: A Theoretical Study and A Proposal for A Semiotic-functional Integrative Model. Netherland: Universiteit Gent.

Yang, B. 2018. "Textual Metaphor Revisited." Australian Journal of Linguistics 38 (2): 205-222. doi:10.1080/07268602.2018.1400502.

Yang, B. 2019. "Interpersonal metaphor revisited: categorization, Identification and syndrome." Social Semiotics 29 (2): 186-203. doi:10.1080/10350330.2018.1425322.

Yang, Y. 2014. Grammatical Metaphor in Chinese. London: Equinox. 